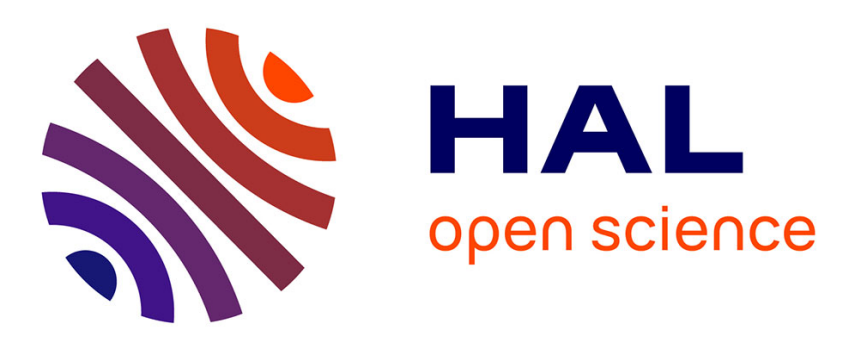

\title{
Structure of nanocrystalline phyllomanganates produced by freshwater fungi
}

\author{
Sylvain Grangeon, Bruno Lanson, Naoyuki Miyata, Yukinori Tani, Alain \\ Manceau
}

\section{> To cite this version:}

Sylvain Grangeon, Bruno Lanson, Naoyuki Miyata, Yukinori Tani, Alain Manceau. Structure of nanocrystalline phyllomanganates produced by freshwater fungi. The American Mineralogist, 2010, 95 (11-12), pp.1608-1616. 10.2138/am.2010.3516 . insu-00544688

\section{HAL Id: insu-00544688}

https://hal-insu.archives-ouvertes.fr/insu-00544688

Submitted on 9 Nov 2011

HAL is a multi-disciplinary open access archive for the deposit and dissemination of scientific research documents, whether they are published or not. The documents may come from teaching and research institutions in France or abroad, or from public or private research centers.
L'archive ouverte pluridisciplinaire HAL, est destinée au dépôt et à la diffusion de documents scientifiques de niveau recherche, publiés ou non, émanant des établissements d'enseignement et de recherche français ou étrangers, des laboratoires publics ou privés. 


\title{
Structure of nanocrystalline phyllomanganates produced by freshwater fungi
}

\section{Sylvain Grangeon, ${ }^{1, *, \uparrow}$ Bruno Lanson, ${ }^{1, *}$ NAOyUki Miyata, ${ }^{2,3}$ YUKinORI TAni, $^{2}$ AND ALAIN MANCEAU ${ }^{1}$}

\author{
${ }^{1}$ Mineralogy and Environments Group, Laboratoire de Géodynamique des Chaines Alpines, Université J. Fourier, \\ CNRS, F-38041 Grenoble Cedex 9, France \\ ${ }^{2}$ Institute for Environmental Sciences, University of Shizuoka, Shizuoka 422-8526, Japan \\ ${ }^{3}$ Department of Biological Environment, Akita Prefectural University, Shimoshinjo-Nakano, Akita 010-0195, Japan
}

\begin{abstract}
The crystal structures of biogenic Mn oxides produced by three fungal strains isolated from stream pebbles were determined using chemical analyses, XANES and EXAFS spectroscopy, and powder $\mathrm{X}$-ray diffraction. The fungi-mediated oxidation of aqueous $\mathrm{Mn}^{2+}$ produces layered Mn oxides analogous to vernadite, a natural nanostructured and turbostratic variety of birnessite. The crystallites have domain dimensions of $\sim 10 \mathrm{~nm}$ in the layer plane (equivalent to $\sim 35 \mathrm{MnO}_{6}$ octahedra), and $\sim 1.5-2.2$ $\mathrm{nm}$ perpendicularly (equivalent to $\sim 2-3$ layers), on average. The layers have hexagonal symmetry and from 22 to $30 \%$ vacant octahedral sites. This proportion likely includes edge sites, given the extremely small lateral size of the layers. The layer charge deficit, resulting from the missing layer $\mathrm{Mn}^{4+}$ cations, is balanced mainly by interlayer $\mathrm{Mn}^{3+}$ cations in triple-corner sharing position above and/or below vacant layer octahedra. The high surface area, defective crystal structure, and mixed $\mathrm{Mn}$ valence confer to these bio-minerals an extremely high chemical reactivity. They serve in the environment as sorption substrate for trace elements and possess catalytic redox properties.
\end{abstract}

Keywords: Manganese oxide, birnessite, biominerals, phyllomanganate, crystal structure

\section{INTRODUCTION}

The structural characterization of nanocrystalline biominerals is an expanding field of study because of their natural abundance and high capacity to sorb trace metals. Chemically reactive nano-manganese dioxides can be produced by a variety of living organisms including bacteria, fungi, and plants (Mandernack et al. 1995; Tani et al. 2003, 2004a; Jürgensen et al. 2004; Miyata et al. 2004, 2007a, 2007b; Tebo et al. 2004; Bargar et al. 2005, 2009; Webb et al. 2005, 2006; Saratovsky et al. 2006; Toner et al. 2006; Villalobos et al. 2006; Lanson et al. 2008; Spiro et al. 2010). The biotic oxidation of $\mathrm{Mn}^{2+}$ to $\mathrm{Mn}^{4+}$ is approximately two orders of magnitude faster than the heterogeneous oxidation catalyzed by mineral surfaces, thus supporting the currently held view that the biogenic route to Mn oxide formation prevails in nature (Crerar and Barnes 1974; Tebo and Emerson 1985; Sunda and Huntsman 1988; Tebo 1991; Tebo et al. 2004; Morgan 2005; De Schamphelaire et al. 2007). Vernadite, a nanosized phyllomanganate consisting of randomly stacked layers of edge-sharing $\left(\mathrm{Mn}^{4+} \mathrm{O}_{6}\right)^{8-}$ octahedra (Giovanoli 1980), is the main biogenic Mn oxide (Jürgensen et al. 2004; Bargar et al. 2005; Webb et al. 2005; Villalobos et al. 2006; Lanson et al. 2008), possibly with tectomanganates, such as todorokite (e.g., Tebo et al. 2004). However, because phyllomanganates can transform into tectomanganates in the solid-state by topot-

\footnotetext{
* E-mail: Sylvain.Grangeon@obs.ujf-grenoble.fr

+ Present address: BRGM, 3 av. Claude Guillemin, F-45060 Orléans cedex 2, France.
}

actic reactions (Bodei et al. 2007), vernadite may be the sole oxidation product of $\mathrm{Mn}^{2+}$. Well-crystallized phyllomanganates, such as birnessite, owe their surface reactivity to the presence of vacant layer sites and/or to $\mathrm{Mn}^{3+}$ for $\mathrm{Mn}^{4+}$ substitutions that confer to the layer a charge deficit up to three times higher than that of smectite (Brindley 1980; Drits et al. 1997; Silvester et al. 1997; Lanson et al. 2000). Vernadite is even more reactive because very small particles have in addition high amounts of border sites. The ratio of external to internal $\mathrm{Mn}$ sites increases when the crystal size decreases, and biogenic vernadite with a layer dimension of 6-7 $\mathrm{nm}$ (Lanson et al. 2008) has $\sim 20 \%$ of its $\mathrm{Mn}$ atoms exposed at the crystal edge compared to $\sim 0.4 \%$ for a birnessite layer of $\sim 30 \mathrm{~nm}$ in diameter (Lanson et al. 2000). Thus, organic pollutants can be degraded and trace metals taken up by vernadite in natural systems (McKenzie 1980; Stone 1987; Stone and Ulrich 1989; Sunda and Kieber 1994; Manceau et al. 2003, 2004, 2007a, 2007b; Villatoro-Monzón et al. 2003; Marcus et al. 2004a; Tebo et al. 2004; Hochella et al. 2005a, 2005b; Isaure et al. 2005; Villalobos et al. 2005; Peacock and Sherman 2007; Peacock 2009).

The production and sorption capacity of fungal vernadite are well documented (Tani et al. 2003, 2004a; Miyata et al. 2004, 2007a, 2007b), but progress in the interpretation and modeling of sorption data are limited by the lack of a comprehensive structure model (Appelo and Postma 1999; Tonkin et al. 2004). In the present study, chemical analyses, X-ray absorption near edge structure (XANES) and extended X-ray absorption fine structure (EXAFS) spectroscopy, and powder X-ray diffraction (XRD) were combined to determine the nature and amounts of 
structural defects in vernadite produced by three fungal strains. The total density of reactive surface sites is shown to be similar in vernadite formed by fungi and plants, and much higher in biotic vernadite than in laboratory-derived chemical analogs.

\section{MATERIALS AND EXPERIMENTAL METHODS}

\section{Preparation of biogenic manganese oxides}

Three ascomycete fungi, Acremonium sp. strain KR21-2 and unclassified Pleosporales strains IRB20-1 and IRB20-2, were isolated from manganese coatings on stream pebbles (Kikukawa River System, Shizuoka, Japan), and the enzymatic $\mathrm{Mn}^{2+}$ oxidation characterized previously by biochemical methods (Tani et al. 2003; Miyata et al. 2006a, 2006b). Biogenic oxides were produced by cultivation of the fungal strains at $25^{\circ} \mathrm{C}$ for $72 \mathrm{~h}$ in a HEPES-buffered HAY medium with $\mathrm{MnSO}_{4}$ as $\mathrm{Mn}$ source. Culture conditions are detailed in Miyata et al. (2004). The $\mathrm{Mn}^{2+}$ oxidation products and grown cells were collected together by centrifugation (3000 g, $15 \mathrm{~min})$.

\section{Chemical analysis}

Total $\mathrm{Mn}, \mathrm{Na}, \mathrm{Mg}$, and $\mathrm{K}$ contents were measured by inductively coupled plasma-atomic emission spectrometry (ICP-AES, Perkin-Elmer Optima 3000) on aliquots of solutions obtained from $\sim 5 \mathrm{mg}$ Mn oxide and cell powder digested in $\sim 15 \mathrm{~mL} \mathrm{NH}_{3} \mathrm{OHCl}(0.7 \mathrm{~mol} / \mathrm{L}, \mathrm{pH} 1.9)$ for $1 \mathrm{~min}$ to minimize the cell dissolution. Mean manganese oxidation degrees were measured by potentiometric titration, using Mohr salt and $\mathrm{Na}_{4} \mathrm{P}_{2} \mathrm{O}_{7}$ (Lingane and Karplus 1946; Vetter and Jaeger 1966; Gaillot 2002).

\section{X-ray diffraction}

Powder XRD patterns were collected using a Bruker D5000 diffractometer equipped with a SolX solid-state detector over the 5-80 ${ }^{\circ} 2 \theta$ angular interval ( $\mathrm{CuK \alpha}$ radiation, $\lambda=1.5418 \AA$ ) with $40 \mathrm{~s}$ counting time per $0.04^{\circ} 2 \theta$ step. Since the structure is turbostratic, the periodicity is only two-dimensional and the XRD patterns have no $h k l$ reflections (Warren 1941). Thus, three-dimensional unit-cell parameters and space groups cannot be defined, and structure models can be determined only by modeling the scattered X-ray intensity to theoretical models, as described previously (Manceau et al. 1997; Drits et al. 1998; Lanson et al. 2000, 2002a, 2002b, 2008; Gaillot et al. 2004, 2005; Villalobos et al. 2006; Grangeon et al. 2008). The sensitivity of XRD to structural parameters, including the size of coherent scattering domains (CSD sizes), $a$ and $b$ lattice parameters, atomic positions, and site occupancies has been discussed elsewhere (Manceau et al. 1997; Villalobos et al. 2006; Grangeon et al. 2008; Lanson et al. 2008). For example, the uncertainty on the number of interlayer $\mathrm{Mn}$ in triple-corner sharing position above/below layer vacancies (TC position) is estimated to be \pm 0.01 atom per octahedral site.

\section{XANES and EXAFS spectroscopy}

Manganese $K$-edge XANES and EXAFS spectra were recorded on beamline 10.3.2 at the Advanced Light Source, Berkeley, U.S.A. (Marcus et al. 2004b). The absolute energy of the XANES spectra is referenced to the maximum of the first inflection point of elemental Mn set at $6539 \mathrm{eV}$. EXAFS spectra were extracted from X-ray absorption data with a software developed in-house and simulated with WinXas using the single-scattering approximation (Ressler 1998). The amplitude reduction factor $\left(S_{0}^{2}\right)$ was calibrated against $\lambda-\mathrm{MnO}_{2}$ (Villalobos et al. 2006) and determined to be equal to 0.8 .

\section{RESULTS}

\section{Chemical data}

Manganese is logically the predominant cation in the fungal $\mathrm{Mn}$ oxides, $\mathrm{K}, \mathrm{Ca}$, and $\mathrm{Mg}$ being minor, and $\mathrm{Na}$ marginal. The $\mathrm{K} / \mathrm{Mn}, \mathrm{Ca} / \mathrm{Mn}, \mathrm{Mg} / \mathrm{Mn}$, and $\mathrm{Na} / \mathrm{Mn}$ atomic ratios for $\mathrm{KR} 21-2$ are $0.0411( \pm 0.0012), 0.0291( \pm 0.0010), 0.0403( \pm 0.0010)$, and $0.0064( \pm 0.0010)$, respectively, and $0.0518( \pm 0.0016), 0.0233$ ( \pm 0.0013$), 0.0257( \pm 0.0013)$, and $0.0022( \pm 0.0012)$ for IRB20-2. Uncertainties were calculated from triplicates and expressed as standard errors (Webster 2001). Sample IRB20-1 was not analyzed due to the insufficient amount of material. Measured manganese oxidation degrees are 3.38 (KR21-2), 3.37 (IRB20-1), and 3.35 (IRB20-2). Measurements could not be replicated, due to the limited supply of material, and their precision is limited anyway by interactions between organic matter and reactants during titration. Although semi-quantitative, these values are much lower than 4 and agree, within $10 \%$, with the value reported for the biogenic Mn oxide produced by Leptotrix discophora (3.6, Adams and Ghiorse 1988). Thus, Mn is expected to be present in the mineral structure not only as $\mathrm{Mn}^{4+}$, but also as $\mathrm{Mn}^{2+/ 3+}$.

\section{Qualitative description of XRD patterns}

XRD patterns are typical of turbostratic birnessite with faint $00 l$ basal reflections in the low-angle region $\left(5-30^{\circ} 2 \theta\right)$ and $h k$ diffraction bands at higher angles (30-80 $2 \theta$ ) (Fig. 1; Drits et al. 1997, 2007; Jürgensen et al. 2004; Villalobos et al. 2006; Lanson et al. 2008). Fungal cells have a scattering intensity that rises at $16^{\circ} 2 \theta$, plateaus at $20-40^{\circ} 2 \theta$, and decreases steadily afterward. The maximum at $\sim 11.8^{\circ} 2 \theta(\sim 7.5 \AA)$ of the manganese samples is only from the 001 basal reflection of vernadite, whereas both the 002 reflection and the scattering of dead cells contribute to the broad maximum between 16 and $28{ }^{\circ} 2 \theta$. The 001 reflection is well defined for KR21-2, and faint for IRB20-1 and IRB20-2, meaning that the diffracting crystallites contain more layers stacked coherently along the $c^{*}$ axis in the first sample (i.e., the CSD size in this direction is larger). On the basis of qualitative comparison with theoretical XRD calculations (Fig. 9 in Lanson et al. 2008), vernadite crystallites contain at most three layers on average.

The maxima at $\sim 36.8^{\circ} 2 \theta(2.44 \AA), \sim 66.3^{\circ} 2 \theta(1.41 \AA)$, and $\sim 78.4^{\circ} 2 \theta$ (1.22 $\AA$ ) match the $d$-spacings for the $11,20,31,02$, and 22,40 diffraction bands of a C-centered two-dimensional unit cell (Drits et al. 1997, 2007; Lanson et al. 2000, 2008; Webb et al. 2005; Villalobos et al. 2006; Grangeon et al. 2008). The ratio of the $d$-spacings for the 11,20 and 31,02 bands $(\sim 1.73)$ is close to $\sqrt{3}$, thus indicating hexagonal layer symmetry. This symmetry is confirmed by the symmetrical shape of the 31,02 band, as the 31 and 02 contributions are split when the layer symmetry is orthogonal $(a>\sqrt{3} \times b$; Webb et al. 2005; Drits et al. 2007; Lanson et al. 2008). This band is at the same position for IRB20-1 and IRB20-2, but shifted to lower $2 \theta$ values for KR21-2, indicative of larger in-plane unit-cell parameters (Fig. 1, inset).

In contrast to the 31,02 diffraction band, the high-angle side of the 11,20 band of turbostratic phyllomanganates is sensitive to their layer and interlayer structures (Villalobos et al. 2006; Drits et al. 2007; Manceau et al. 2007b; Grangeon et al. 2008; Lanson et al. 2008). The lineshape depends on the nature, density, and position of interlayer species, more specifically on the proportion of high-Z elements ( $\mathrm{Mn}$ in the present case) in TC position. The XRD pattern of KR21-2 resembles that of NidBi177-7, a sample containing $\sim 0.20$ "heavy" interlayer species (Ni and Mn) in TC position per layer octahedron (Supplementary Fig. $1^{1}$ ). In both cases, the 11,20 scattering tail decreases regularly in the 38-46 ${ }^{\circ} 2 \theta$ interval with a minimum at $\sim 46^{\circ} 2 \theta$, which is absent when there is only 0.10 heavy atoms in the interlayer (solid arrows in Supplementary Fig. $1^{1}$ ). This minimum is also observed in IRB20-1 and IRB20-2, but their patterns have in addition a 


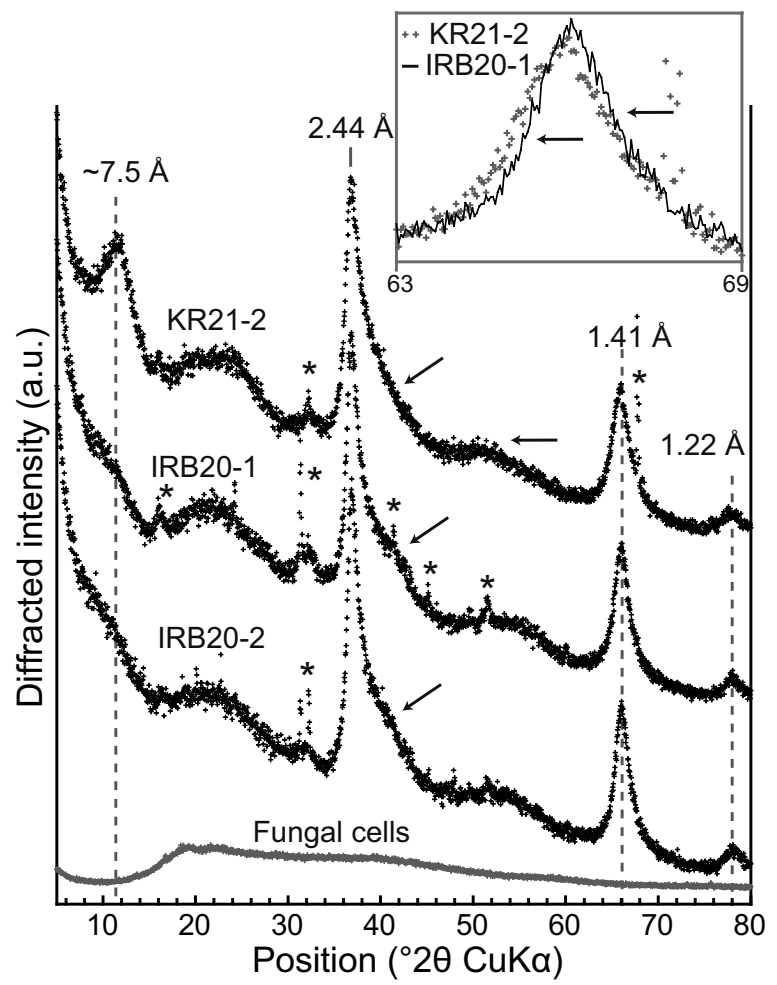

FIGURE 1. X-ray diffraction patterns of fungal Mn oxides and fungal cells. Arrows point out the contrasted modulations of the 11,20 band. Stars indicate diffraction lines related to impurities and sample holder. Inset: 31,02 diffraction band of KR21-2 (crosses) and IRB20-1 (solid line).

shoulder at $\sim 42^{\circ} 2 \theta$ (dashed arrows in Supplementary Fig. $1^{1}$ ), indicative of higher amounts of interlayer Mn than KR21-2 (Fig. 13 in Drits et al. 2007). Calculated XRD patterns suggest that the two IRB samples contain at least 0.3 interlayer Mn, and thus at least $15 \%$ layer vacancies. Finally, the three fungal samples have a 11,20 diffraction band sharper than those of Ni-sorbed $\delta$ - $\mathrm{MnO}_{2}$ (Supplementary Fig. $\left.1^{1}\right)$, thus indicating higher CSD sizes in the $a-b$ plane (diameter $>5 \mathrm{~nm}$ ).

\section{Quantitative analysis of XRD patterns}

The $h k$ diffraction bands were simulated first because the layer and interlayer structures need to be known to calculate the intensities of the $00 l$ reflections. Optimum simulations of $h k$ bands were obtained by adjusting for each sample the nature and site occupancies of interlayer species. Atomic positions were varied, but constrained to be the same in all sample simulations, because variations from a sample to another increased the number of degrees of freedom without improving significantly the fit quality. Best fits to the data are shown in Figure 2 and selected structural parameters are listed in Tables 1 and 2. The

\footnotetext{
${ }^{1}$ Deposit item AM-10-054, Appendix Figures 1-4. Deposit items are available two ways: For a paper copy contact the Business Office of the Mineralogica Society of America (see inside front cover of recent issue) for price information. For an electronic copy visit the MSA web site at http://www.minsocam.org, go to the American Mineralogist Contents, find the table of contents for the specific volume/issue wanted, and then click on the deposit link there.
}

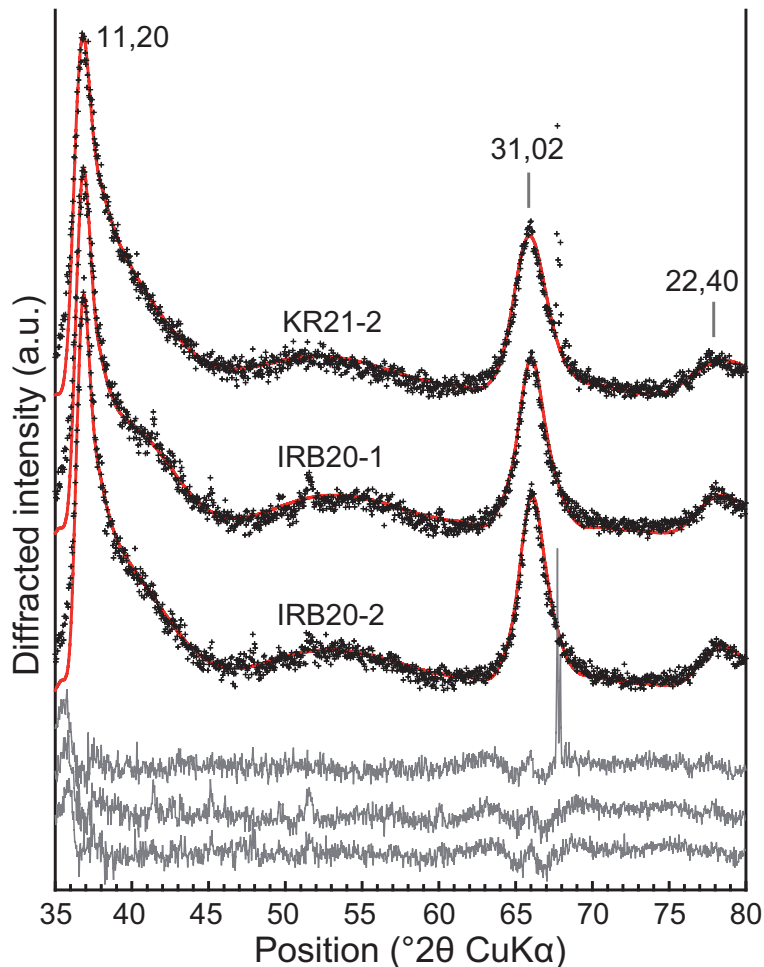

FIGURE 2. Experimental (black crosses) and calculated (red lines) intensities of the 11,20, 31,02, and 22,40 bands. Difference plots are shown at the bottom of the figure. The structure models are described in Tables 1 and 2. The cell contribution (Fig. 1) and the scattering background were subtracted from the experimental data before modeling.

domain sizes are $\sim 10 \mathrm{~nm}$ in the layer plane and $\sim 1.5-2.2 \mathrm{~nm}$ (2-3 layers) perpendicular to it. From 22 to $30 \%$ of the layer sites are vacant, thus creating a high charge deficit for the layer compensated for mainly by $\mathrm{Mn}$ atoms in TC sites $\left({ }^{\mathrm{TC}} \mathrm{Mn}\right.$ $=0.250-0.365$ per layer octahedron). The layer charge deficit is balanced also by minor ${ }^{\mathrm{TE}} \mathrm{Mn}$ (i.e., Mn sorbed above/below tridentate cavities sharing three edges with layer octahedra, see for example Grangeon et al. 2008), ${ }^{\mathrm{TC}} \mathrm{Mg}$, and $\mathrm{K}^{+}$in the interlayer mid-plane. This plane also contains $\mathrm{H}_{2} \mathrm{O}$ molecules coordinated to interlayer cations and $\mathrm{H}$-bonded to $\mathrm{O}$ atoms from adjacent layers $\left[d\left(\mathrm{O}_{\mathrm{H}_{2} \mathrm{O}}-\mathrm{O}_{\text {layer }}\right) \sim 2.7 \AA\right]$.

The basal reflections were reproduced next by using the layer and interlayer parameters determined previously and by optimizing the CSD size along the $c^{*}$ direction (Supplementary Fig. $2^{1}$ ). Sample IRB20-1 contains on average 2.4 layers per crystallite, IRB20-2 2.1, and KR21-2 3.0. CSDs along the $c^{*}$ direction are thus $50 \%$ larger in KR21-2 than in IRB20-2 for a fivefold peak intensity (Table 1; Supplementary Fig. $2^{1}$ ). This comparison exemplifies the high sensitivity of XRD to the structure of vernadite despite its vanishingly small size and high degree of structural disorder.

\section{XANES and EXAFS spectroscopy}

The proportions of $\mathrm{Mn}^{4+}, \mathrm{Mn}^{3+}$, and $\mathrm{Mn}^{2+}$ were evaluated using least-squares fitting of the XANES spectra with linear combinations of chalcophanite $\left(\mathrm{Mn}^{4+}\right)$, feitknechite $\left(\mathrm{Mn}^{3+}\right)$, and 
TABLE 1. Crystal data derived from XRD

\begin{tabular}{|c|c|c|c|c|c|c|c|}
\hline \multirow[t]{2}{*}{ Sample } & \multirow[t]{2}{*}{$a(\AA)^{*}$} & \multirow[t]{2}{*}{$b(\AA)^{*}$} & \multirow[t]{2}{*}{$d(001)(\AA)$} & \multicolumn{2}{|c|}{ Average crystallite size $\dagger$} & \multirow[t]{2}{*}{$R_{\mathrm{wp}}(\%) \ddagger$} & \multirow[t]{2}{*}{ G.o.f. $\neq$} \\
\hline & & & & In the $a-b$ plane $(\mathrm{nm})$ & Along $c^{*}$ & & \\
\hline KR21-2 & 4.929 & 2.846 & 7.2 & 8.8 & 3.0 & $4.78-6.68$ & $4.00-4.35$ \\
\hline IRB20-1 & 4.916 & 2.838 & 7.2 & 9.8 & 2.4 & $5.95-6.00$ & $6.54-3.63$ \\
\hline IRB20-2 & 4.914 & 2.837 & 7.2 & 10.8 & 2.1 & $4.16-4.10$ & $2.24-2.71$ \\
\hline
\end{tabular}

Note: For discussion of estimated uncertainties, see text.

* Values determined from the position of the 31,02 band.

†The CSD size is expressed as the mean diameter of the disk-shaped domains in the $a-b$ plane and as the mean number of layers stacked along the $c^{*}$ axis.

$\neq$ The first value was calculated over the low-angle region, and the second over the high-angle region. Parameters after Howard and Preston (1989).

TABLE 2. Structural parameters derived from XRD

\begin{tabular}{|c|c|c|c|c|c|c|}
\hline \multirow[t]{2}{*}{$\overline{\text { Atom }}$} & \multicolumn{3}{|c|}{ Coordinates* } & \multicolumn{3}{|c|}{ Site occupancy† } \\
\hline & $x$ & $y$ & $\zeta$ & KR21-2 & IRB20-1 & IRB20-2 \\
\hline$M n(M n 1)$ & 0 & 0 & 0 & 0.78 & 0.70 & 0.74 \\
\hline $\mathrm{O}_{\mathrm{Mn} 1}(\mathrm{O} 1)$ & 0.333 & 0 & 1.00 & 2.00 & 2.00 & 2.00 \\
\hline${ }^{\mathrm{TC}} \mathrm{Mn}(\mathrm{Mn} 2)$ & 0 & 0 & 2.15 & 0.25 & 0.365 & 0.325 \\
\hline $\mathrm{O}_{\mathrm{Mn} 2}(\mathrm{O} 2)$ & -0.333 & 0 & 3.40 & 0.75 & 1.095 & 0.975 \\
\hline${ }^{\mathrm{TE}} \mathrm{Mn}(\mathrm{Mn} 3)$ & -0.333 & 0 & 2.15 & - & 0.02 & - \\
\hline $\mathrm{O}_{\mathrm{Mn} 3}(\mathrm{O} 3)$ & 0 & 0 & 3.40 & - & 0.06 & - \\
\hline${ }^{\mathrm{TC}} \mathrm{Mg}\left(\mathrm{Mg}^{2+}\right)$ & 0 & 0 & 2.30 & 0.04 & - & - \\
\hline $\mathrm{O}_{\mathrm{Mg}^{2+}}(\mathrm{O} 4)$ & 0 & 0 & 3.60 & 0.12 & - & - \\
\hline $\mathrm{K}^{+}$ & -0.203 & 0 & 3.60 & 0.01 & 0.02 & 0.02 \\
\hline $\mathrm{K}^{+}$ & -0.4167 & 0.125 & 3.60 & 0.01 & 0.02 & 0.02 \\
\hline $\mathrm{K}^{+}$ & -0.4167 & -0.125 & 3.60 & 0.01 & 0.02 & 0.02 \\
\hline $\mathrm{H}_{2} \mathrm{O}_{\text {interlayer }}(\mathrm{O} 5)$ & 0.200 & 0 & 3.60 & 0.12 & 0.08 & 0.08 \\
\hline $\mathrm{H}_{2} \mathrm{O}_{\text {interlayer }}(\mathrm{O} 5)$ & -0.100 & 0.300 & 3.60 & 0.12 & 0.08 & 0.08 \\
\hline $\mathrm{H}_{2} \mathrm{O}_{\text {interlayer }}(\mathrm{O} 5)$ & -0.100 & -0.300 & 3.60 & 0.12 & 0.08 & 0.08 \\
\hline
\end{tabular}

Notes: Symmetry operations: $(x, y, z),(-x,-y,-z),(x+1 / 2, y+1 / 2, z),(-x+1 / 2,-y+1 / 2$, $-z)$. The $C 2 / m$ space group can be used to represent the structure model. However, care has to be taken to not generate equivalent positions from adjacent layers because vernadite has no 3D periodicity. For discussion of estimated uncertainties, see text.

* Atomic coordinates $x$ and $y$ are expressed as fractions of the $a$ and $b$ parameters, respectively. Coordinates along the $c^{*}$ axis ( () are expressed in $\AA ̊$ to emphasize the thickness of layer and interlayer polyhedra.

+Occupancies are given per half unit cell (i.e., per octahedral layer site), and as the sum of the $(x, y, z)$ and $(-x,-y,-z)$ equivalent sites. The Debye-Waller thermal factors $(B)$ were fixed to $0.5 \AA^{2}$ for $\mathrm{Mn} 1,1.0 \AA^{2}$ for $\mathrm{O} 1,2.0 \AA^{2}$ for $\mathrm{O} 6$ and $\mathrm{K}^{+}$, and $1.5 \AA^{2}$ for the other species.

$\mathrm{Mn}^{2+}$-sorbed fungi (strain IRB20-1) as model compounds. The spectrum of KR21-2 was best-fit with $15 \% \mathrm{Mn}^{2+}+10 \% \mathrm{Mn}^{3+}$ $+73 \% \mathrm{Mn}^{4+}$, those of IRB20-1 and IRB20-2 with $18 \% \mathrm{Mn}^{2+}+$ $12 \% \mathrm{Mn}^{3+}+69 \% \mathrm{Mn}^{4+}$ (Fig. 3). The precision was evaluated by varying incrementally the amount of $\mathrm{Mn}^{3+}$ and optimizing the proportions of the two other species (Supplementary Fig. $3^{1}$ ). The fit was visually degraded for a twofold increase of the normalized sum-square difference between the data and the reconstructed spectra, leading to a precision of about $10 \%$ of total $\mathrm{Mn}$ for $\mathrm{Mn}^{3+}$ and $\mathrm{Mn}^{4+}$, and of less than $5 \%$ for $\mathrm{Mn}^{2+}$.

The EXAFS spectra of the three biogenic oxides have similar amplitude, shape, and frequency, meaning that the three oxides have essentially the same structure (Fig. 4). The shape and frequency of their EXAFS spectra resemble those of $\mathrm{HBi}$, a birnessite reference with hexagonal layer symmetry and $\sim 0.17$ vacant layer sites per layer octahedron capped by a similar number of ${ }^{\mathrm{TC}} \mathrm{Mn}$ (Silvester et al. 1997). If the layer symmetry of the biogenic oxides was orthogonal, the oscillation at $\sim 8.2$ $\AA^{-1}$ would be split, and not symmetrical as observed (Gaillot et al. 2003; Manceau et al. 2004, 2005; Marcus et al. 2004a). The main difference between the fungal oxides and HBi spectra is a reduction in amplitude in the biogenic oxides, which likely is a combination of particle size effect as outer Mn octahedra on layer edges have fewer Mn neighbors, and of disorder effect as heterovalent $\mathrm{Mn}$ atoms have distinct $\mathrm{Mn}-\mathrm{O}$ distances.
On closer examination of EXAFS spectra, it appears that the maximum of the second oscillation is shifted to higher $k$ values by $\sim 0.15 \AA^{-1}$ for IRB20-1, thus reinforcing the shoulder at $\sim 6.5$ $\AA^{-1}$. This observation suggests that this sample contains more ${ }^{\mathrm{TC}} \mathrm{Mn}$, because this feature is a fingerprint of "heavy" scattering atoms at TC position (Manceau et al. 1997; Silvester et al. 1997; Villalobos et al. 2006). This interpretation agrees with XRD results because this sample has the highest TC occupancy ( 0.365 per octahedron; see Table 2$)$. However, this increase is not reflected in the EXAFS simulations, due perhaps to the low precision of EXAFS coordination numbers (typically $\pm 20 \%$; see Manceau et al. 2005).

The amplitude reduction relative to HBi manifests itself in the $R$-space by a decrease of the Mn-O1, Mn-Mn1, and Mn$\mathrm{Mn} 2$ peaks corresponding to the oxygen coordination shell, edge-sharing layer octahedra, and corner-sharing Mn octahedra, respectively (Fig. 4b; Manceau and Combes 1988). The decrease in amplitude of the Mn-Mn2 peak (layer $\mathrm{Mn}^{\mathrm{TC}} \mathrm{Mn}$ pairs) is con-

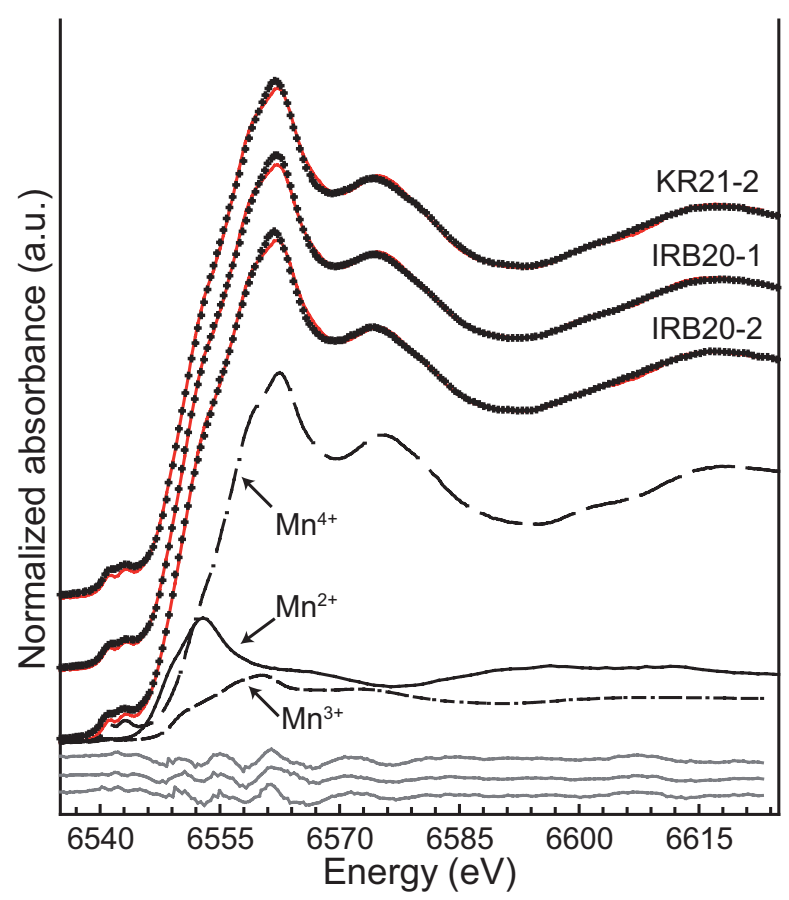

FigURE 3. XANES spectra of fungal Mn oxides. Red lines are the best-fit linear combinations to data (crosses), using $\mathrm{Mn}^{4+}$ (chalcophanite), $\mathrm{Mn}^{3+}$ (feitknechite), and $\mathrm{Mn}^{2+}$ (sorbed on IRB20-1 fungal cells) references. Difference plots are shown at the bottom of the figure. 

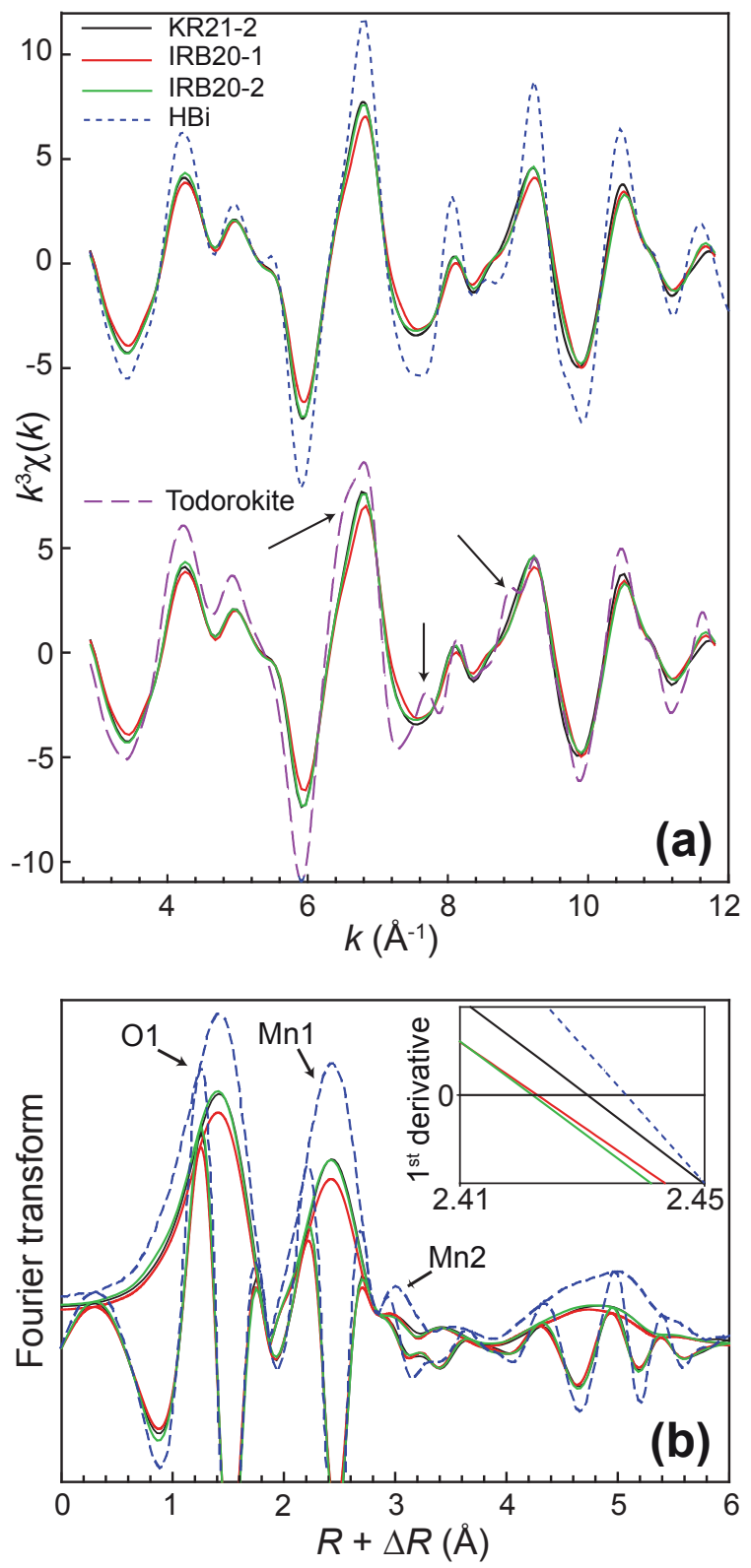

Figure 4. (a) Mn $K$-edge EXAFS spectra of KR21-2 (black), IRB20-1 (red), IRB20-2 (green), and the HBi pH 4 and todorokite references (dashed blue and dashed purple); (b) modulus and imaginary parts of the Fourier transforms (uncorrected for phase shift) from the biogenic EXAFS spectra in a and HBi. Inset: first derivative of the Mn-Mn1 peak.

sistent with the small size of the biogenic layers, because ${ }^{\mathrm{TC}} \mathrm{Mn}$ located at layer edges are surrounded by two to three layer Mn instead of six on basal planes (Fig. 3 in Manceau et al. 2007b). The first derivative of the Mn-Mn1 peak varies in position from sample to sample. Relative to $\mathrm{HBi}$, it is shifted by $-0.015 \AA$ for IRB20-2, $-0.014 \AA$ for IRB20-1, and -0.006 $\AA$ KR21-2 (Fig. 4b, inset). This evolution follows the variation in $b$ values determined by XRD: $2.848 \AA$ for $\mathrm{HBi}$ at $\mathrm{pH} 4$ (Lanson et al. 2000), $2.837 \AA$ for IRB20-2 $(\Delta b=-0.011 \AA), 2.838 \AA$ for IRB20-1 $(\Delta b=-0.010$ $\AA)$, and $2.846 \AA$ for KR21-2 $(\Delta b=-0.002 \AA)$.

Single-scattering simulations of the $k^{3} \chi(k)$ EXAFS data filtered in the 0.8-3.3 $\AA R+\Delta R$ interval show an apparent loss of coordination of the Mn-O1 shell, from nominally 6 for an octahedron to effectively $3.3-3.7$, as a result of the multiplicity of oxidation states $(2+, 3+, 4+)$, site occupancies (layer, interlayer, edges), and types of ligands $\left(\mathrm{O}, \mathrm{OH}, \mathrm{H}_{2} \mathrm{O}\right.$ - Table 3; Supplementary Fig. $\left.4^{1}\right)$. The multiplicity of bonding environments, as well as layer vacancies and border effects due to the small size of the layers, also reduce the number of Mn-Mn1 pairs from 6 to $3.0-3.5$.

\section{DISCUSSION}

\section{Structure of fungal-mediated oxidation products}

The present study shows, in agreement with previous ones (Tani et al. 2004a, 2004b; Miyata et al. 2006a, 2006b, 2007b), that the manganese oxides produced by the fungal-mediated oxidation of aqueous $\mathrm{Mn}^{2+}$ have a layered structure analogous to vernadite. However, it has been speculated recently that the minerals formed by the fungus KR21-2 are analogous to todorokite, a tectomanganate with a $3 \times 3$ tunnel size (Saratovsky et al. 2009). This interpretation relies on the qualitative comparison of XRD and EXAFS data from the biogenic oxide with those from todorokite and birnessite as model compounds, and the simulation of the fungal EXAFS spectrum with a todorokite-like model. Several aspects of this study are questionable.

Despite the recent demonstrations of the successful modeling of XRD patterns from turbostratic phyllomanganates (Villalobos et al. 2006; Grangeon et al. 2008; Lanson et al. 2008), Saratovsky et al. (2009) stated that detailed structural characterization from XRD profiles exhibiting only a few broad diffraction lines is challenging, and thus was not attempted. In addition, the qualitative comparison of the fungal XRD pattern with those calculated for disordered todorokite and birnessite was meant to be inconclusive, because of the systematic occurrence of maxima at 2.44 and $1.41 \AA$ in all $\mathrm{MnO}_{\mathrm{x}}$ structures, including KR21-2. In fact, the $2.44 \AA$ peak is outmatched by a peak at $2.40 \AA$ in todorokite, even when this mineral is poorly crystallized (Bodei et al. 2007; Manceau et al. 2007a). The fungal pattern shown by Saratovsky et al. (2009) has no peak at $2.40 \AA$, and the scattering intensities at $\sim 42$ and $55^{\circ} 2 \theta \mathrm{Cu} K \alpha(2.15$ and $1.67 \AA$, respectively) are similar to those calculated for disordered birnessite. The fungal pattern lacked also the second diagnostic reflection from todorokite at $4.77 \AA\left(\sim 18.6^{\circ} 2 \theta\right.$, Fig. 2 in Saratovsky et al. 2009). A more detailed discussion of the XRD pattern presented by these authors is hampered by the high level of noise in the data and the lack of information on background subtraction.

Similarly to the qualitative approach followed to analyze XRD data, the nature of the biogenic oxides was inferred from EXAFS in the previous study by comparing the fungal spectrum to those from well-crystallized synthetic todorokite and hexagonal birnessite. The $7.5-9.5 \AA^{-1}$ "indicator region," defined originally by Marcus et al. (2004a) and Manceau et al. (2004), appeared to be closer to todorokite than birnessite, in the sense that hexagonal birnessite exhibits two sharp peaks at $\sim 8$ and 9 $\AA^{-1}$ that were absent or indistinct in the two other spectra. Figure 
TABLE 3. Structural parameters derived from EXAFS

\begin{tabular}{|c|c|c|c|c|c|c|c|c|c|c|c|c|c|}
\hline \multirow[t]{3}{*}{ Sample } & & \multicolumn{11}{|c|}{ Atomic pairs } & \multirow[t]{3}{*}{$\Delta E^{*}$} \\
\hline & \multicolumn{3}{|c|}{ Mn-O1 } & \multicolumn{3}{|c|}{$\mathrm{Mn}-\mathrm{O} 2$} & \multicolumn{3}{|c|}{$\mathrm{Mn}-\mathrm{Mn} 1$} & \multicolumn{3}{|c|}{$\mathrm{Mn}-\mathrm{Mn} 2$} & \\
\hline & $\mathrm{CN}$ & $R(\AA)$ & $\sigma^{2}\left(\AA^{2}\right)$ & $\mathrm{CN}$ & $R(\AA ̊)$ & $\sigma^{2}\left(\AA^{2}\right)$ & $\mathrm{CN}$ & $R(\AA ̊)$ & $\sigma^{2}\left(\AA^{2}\right)$ & $\mathrm{CN}$ & $R(\AA)$ & $\sigma^{2}\left(\AA^{2}\right)$ & \\
\hline KR21-2 & 3.5 & 1.90 & 0.003 & 3.5 & 3.60 & 0.003 & 3.4 & 2.89 & 0.007 & 2.0 & 3.48 & 0.007 & 4.8 \\
\hline IRB20-1 & 3.3 & 1.89 & 0.004 & 3.3 & 3.60 & 0.004 & 3.0 & 2.88 & 0.007 & 2.1 & 3.48 & 0.007 & 4.5 \\
\hline IRB20-2 & 3.7 & 1.89 & 0.004 & 3.7 & 3.60 & 0.004 & 3.5 & 2.88 & 0.007 & 2.2 & 3.47 & 0.007 & 4.0 \\
\hline
\end{tabular}

Note: Coordination numbers (CN) and Debye-Waller factors $\left(\sigma^{2}\right)$ of $\mathrm{Mn}-\mathrm{O}$ shells were refined together, as were Debye-Waller factors of the two Mn-Mn shells. $S_{0}^{2}$ was fixed to 0.8 .

* Variation of the energy threshold treated as a single adjustable parameter for all atomic pairs.

4a shows that the two resonances lose momentum with disorder, as for the spectrum of Pseudomonas putida (Villalobos et al. 2006), thus hampering fine distinctions based solely on these two features, especially when the spectra are of low quality in the indicator region. A more conservative EXAFS region to differentiate tectomanganates from phyllomanganates is the 6.0-7.0 $\AA^{-1}$ interval (Fig. 4a; Manceau and Combes 1988). The increased number of ${ }^{\mathrm{TC}} \mathrm{Mn}$ linkages in tectomanganates reinforces the shoulder at $6.5 \AA^{-1}$, thus broadening the second oscillation and rounding its maximum as shown in the Figure 6 of Saratovsky et al. (2009). Using that feature as a fingerprint for the nature of the fungal manganate species, the data from both the previous and this new study consistently show that this biogenic Mn oxide is a phyllomanganate.

Also problematic in the previous EXAFS study are the obvious structural and physical errors in the least-squares fit of the fungal EXAFS spectrum. The EXAFS spectrum is said to have been reproduced successfully with a defect-free todorokite-type model, but the coordination number $(\mathrm{CN})$ for manganese in the Mn1 shell was fixed to 6.0 as in a defect-free phyllomanganate instead of 4.7 in todorokite (Manceau and Combes 1988). In addition, $\mathrm{CN}(\mathrm{Mn} 2)$ was floated illogically, and regressed to 1.6 instead of 2.7 in todorokite, whereas the $\mathrm{CN}(\mathrm{Mn} 3)$ shell was fixed to 6.0 as in a defect-free phyllomanganate instead of 3.3 in todorokite. The refined distance of the Mn3 shell is $4.71 \AA$ instead of $\sim \sqrt{3} \times d(\mathrm{Mn}-\mathrm{Mn} 1)=4.84-5.00 \AA$. The Mn-Mn $n_{\text {edge }}$ multiple-scattering distances (5.65 and $5.83 \AA$ ) were not constrained to two times the Mn-Mn1 distances $(2 \times 2.80=5.60$ $\AA$ and $2 \times 2.89=5.78 \AA$ ), and some Debye-Waller parameters had meaningless values of $0.020-0.033 \AA^{2}$. In the harmonic (i.e., Gaussian) approximation, the distribution of interatomic distances becomes questionable when $\sigma$ is higher than $\sim 0.01$ $\AA^{2}$ (Teo 1986; Crozier 1997). More generally, the hypothesis of a defect-free model compound is inappropriate for a defective nanosized material, and the inability of the birnessite-like model to fit the fungal spectrum was not demonstrated. Therefore, it is unclear how unique was the todorokite-model fit, given all the analytical issues mentioned here.

\section{Valence of interlayer manganese}

Biogenic production of vernadite leads to a complex mixture of mineral and biological constituents. The distribution of cations, and in particular Mn, among the two components is a source of experimental difficulty. $\mathrm{Mn}^{4+}$ and $\mathrm{Mn}^{3+}$ are most likely present in vernadite only, but the partitioning of $\mathrm{Mn}^{2+}$ is less certain, as it can sorb above/below vacant layer sites of the Mn layer and on the organic material (Jürgensen et al. 2004; Webb et al. 2005; Villalobos et al. 2006; Miyata et al. 2007a).
The average oxidation state of $\mathrm{Mn}$ in TC position can be evaluated by calculating the incident bond-valence sum coming from Mn-O bonds (Brese and O'Keeffe 1991; Brown 1996). From XRD data, $<d\left({ }^{\mathrm{TC}} \mathrm{Mn}-\mathrm{H}_{2} \mathrm{O}\right)>=2.06 \AA$ and $\left\langle d\left({ }^{\mathrm{TC}} \mathrm{Mn}-\mathrm{O}_{\text {layer }}\right)>\right.$ $=2.00 \AA ;{ }^{\mathrm{TC}} \mathrm{Mn}$ thus receives $3 \times 0.482+3 \times 0.567=3.147 \mathrm{v} . \mathrm{u}$. if divalent, and $3 \times 0.444+3 \times 0.523=2.901$ v.u. if trivalent, supporting the trivalent character of interlayer Mn. However, one could argue that sorption of metal cations at TC position can move $\mathrm{O}_{\text {layer }}$ in the $a \pm n \times 120^{\circ}(n=1,2,3)$ directions with equal probability (Manceau et al. 2002). In the present case, the structural disorder is too high to detect a possible local relaxation of the $\mathrm{Mn}-\mathrm{O}_{\text {layer }}$ distances by XRD, but the magnitude of the atomic displacement needed to match the formal valence of each Mn species can be calculated. For divalent Mn, the 3.147-2.000 $=1.147 \mathrm{v} . \mathrm{u}$. charge excess could be suppressed by lengthening the $\mathrm{Mn}-\mathrm{O}_{\text {layer }}$ distance from 2.00 to $2.41 \AA$, which would require an unrealistic $\mathrm{O}_{\text {layer }}$ shift of $\sim 0.45 \AA$ in the $a-b$ plane. Thus, ${ }^{\mathrm{TC}} \mathrm{Mn}$ is likely predominantly trivalent, divalent ${ }^{\mathrm{TC}} \mathrm{Mn}$ being at most minor. The majority, if not all, $\mathrm{Mn}^{2+}$ detected by XANES is thus considered to be sorbed on fungal cell walls.

The partial overlap of $\mathrm{Mn}^{2+}, \mathrm{Mn}^{3+}$, and $\mathrm{Mn}^{4+}$ XANES components complicates the quantitative determination of their relative proportions (Fig. 3 and Supplementary Fig. $3^{1}$ ) and is a source of uncertainty as to the actual $\mathrm{Mn}^{3+} / \mathrm{Mn}^{4+}$ ratio in vernadite. Consequently, the number of $\mathrm{Mn}^{3+}$ derived from the $\mathrm{Mn}^{3+}$ / $\mathrm{Mn}^{4+}$ XANES ratio (0.14-0.17) is probably less accurate than the number estimated by XRD from the electron density at the $\mathrm{TC}, \mathrm{TE}$, and $\mathrm{Mn}_{\text {layer }}$ positions $\left(\mathrm{Mn}^{3+} / \mathrm{Mn}^{4+}=0.32-0.55\right.$; Table 2). From these considerations, the following structural formula can be proposed for these nanocrystalline bio-oxides:

$$
\mathrm{M}_{\mathrm{w}}^{+/ 2+}\left(\mathrm{H}_{2} \mathrm{O}\right)_{\mathrm{x}}{ }^{\mathrm{DC} / \mathrm{TC} / \mathrm{TE}} \mathrm{Mn}_{\mathrm{y}} \mathrm{O}_{3 \mathrm{y}}\left[\mathrm{Mn}_{1-\mathrm{z}} \mathrm{O}_{2}\right]
$$

where $\mathrm{M}^{+/ 2+}$ represents protons and alkali, and alkaline earth metal ions. Because interlayer ${ }^{\text {DC/TC/TE }} \mathrm{Mn}$ is essentially trivalent, and computing $\mathrm{M}$ as monovalent equivalents, the compositional variability derived from XRD results (Table 2) is: $0.20 \leq \mathrm{z} \leq$ $0.30 ; 0.25 \leq \mathrm{y} \leq 0.40 ; 0.05 \leq \mathrm{w}=4 \mathrm{z}-3 \mathrm{y} \leq 0.15$; and $0.20 \leq \mathrm{x}$ $\leq 0.40$.

\section{Coordination of interlayer manganese}

The fungal Mn particles being extremely small, they have a high external-to-internal surface ratio. Taking a hexagonal platelet morphology (Webb et al. 2005) and assuming that each edge site hosts two ${ }^{\mathrm{TC}} \mathrm{Mn}$ atoms, due to their strong under-saturation, up to $\sim 40 \%$ of the ${ }^{\mathrm{TC}} \mathrm{Mn}(0.25-0.37$ per layer octahedron - Table 2) could be located on the layer edges, and be in reality ${ }^{\mathrm{DC}} \mathrm{Mn}$ surface complexes (e.g., Manceau et al. 2007b; Grangeon et 
al. 2008). In this configuration, each interlayer Mn shares two corners with two adjacent $\mathrm{Mn}_{\text {layer }}$ octahedra. In addition, some external $\mathrm{Mn}^{3+}$ may be located in the layer plane, sharing two edges with two adjacent $\mathrm{Mn}_{\text {layer }}\left({ }^{\mathrm{DE}} \mathrm{Mn}\right.$ complex-Fig. 14 in Takahashi et al. 2007). If present, ${ }^{\mathrm{DE}} \mathrm{Mn}$ complexes are minor because the layer charge (i.e., $4 z$ in formula 1 ) is close in value to the total charge of $\mathrm{Mn}_{\text {interlayer }}$ (i.e., 3y; Table 2).

\section{Comparison with structure models of vernadite}

The structure model proposed for the phyllomanganates produced by the fungal strains does not differ fundamentally from those proposed previously for biogenic and chemical vernadites (Jürgensen et al. 2004; Villalobos et al. 2006; Lanson et al. 2008; Grangeon et al. 2008; Bargar et al. 2009), and well-crystallized hexagonal birnessites (Manceau et al. 1997; Lanson et al. 2000, 2002b; Drits et al. 2002). The manganese layer contains sparse $\mathrm{Mn}^{3+}$, if any, since its symmetry is hexagonal. As an exception to this generality, orthogonal layer symmetry was observed in the Mn oxide produced by Bacillus sp. strain SG-1, as a result of the abundance and ordering of $\mathrm{Mn}^{3+}$ cations (Drits et al. 1997, 2007; Webb et al. 2005; Gaillot et al. 2007). The layer charge deficit resulting from vacant octahedral sites is balanced essentially by interlayer $\mathrm{Mn}^{3+}$ when the medium is poor in trace metals; otherwise divalent metals, such as $\mathrm{Pb}, \mathrm{Co}, \mathrm{Cu}, \mathrm{Ni}$, and $\mathrm{Zn}$, can compete positively against $\mathrm{Mn}^{3+}$ (McKenzie 1989; Manceau et al. 1997, 2002, 2007a, 2007b; Lanson et al. 2002a; Tani et al. 2004b; Tebo et al. 2004; Peacock and Sherman 2007; Peacock 2009). The charge on layer edges, coming from broken bonds, contributes tangibly to the ion sorption capacity when the layer dimension is small. With a CSD diameter of $\sim 10 \mathrm{~nm}$, the fungal Mn oxides are the second smallest vernadite particules as yet known after those identified in grass roots, which had a CSD diameter of 6-7 nm (Lanson et al. 2008). For comparison, the biogenic vernadite produced by Pseudomonas putida had a mean diameter of $17 \mathrm{~nm}$ (Villalobos et al. 2006).

The total particle charge obtained by summing all interlayer species ( $\mathrm{Mn}, \mathrm{Mg}$, and $\mathrm{K}$ ) is $\sim 0.86-1.22$ v.u. per layer octahedron, a value almost as high as the one obtained for plant vernadite (1.58 v.u. from Lanson et al. 2008), and $\sim 1.2-1.6 \times$ higher than for bacterial vernadite $(\sim 0.74$ v.u. from Villalobos et al. 2006). This high surface charge and the predominance of $\mathrm{Mn}^{3+}$ in the interlayer may explain the superior oxidizing properties of this bio-mineral, in particular for the in situ degradation of organic and inorganic compounds (Cheney et al. 1996; Nasser et al. 2000; Chorover and Amistadi 2001; Villatoro-Monzón et al. 2003; Pizzigallo et al. 2004; Tani et al. 2004a; De Schamphelaire et al. 2007).

\section{ACKNOWLEDGMENTS}

The authors are grateful to Alain Plançon for providing access to his XRD simulation program. Martine Lanson, Delphine Tisserand, and Nicolas Geoffroy are thanked for assistance with chemical analyses, Mn titration, and XRD data collection, respectively. This work was supported by the Université Joseph Fourier through its Pôle TUNES, and by the CNRS EC2CO program.

\section{REFERENCES CITED}

Adams, L.F. and Ghiorse, W.C. (1988) Oxidation state of Mn in the Mn oxide produced by Leptothrix discophora SS-1. Geochimica et Cosmochimica Acta, 52, 2073-2076.
Appelo, C.A.J. and Postma, D. (1999) A consistent model for surface complexation on birnessite $\left(-\mathrm{MnO}_{2}\right)$ and its application to a column experiment. Geochimica et Cosmochimica Acta, 63, 3039-3048.

Bargar, J.R., Tebo, B.M., Bergmann, U., Webb, S.M., Glatzel, P., Chiu, V.Q., and Villalobos, M. (2005) Biotic and abiotic products of $\mathrm{Mn}$ (II) oxidation by spores of the marine Bacillus sp. strain SG-1. American Mineralogist, 90, 143-154.

Bargar, J.R., Fuller, C.C., Marcus, M.A., Brearley, A.J., Perez De la Rosa, M., Webb, S.M., and Caldwell, W.A. (2009) Structural characterization of terrestrial microbial Mn oxides from Pinal Creek, Arizona. Geochimica et Cosmochimica Acta, 73, 889-910.

Bodei, S., Manceau, A., Geoffroy, N., Baronnet, A., and Buatier, M. (2007) Formation of todorokite from vernadite in Ni-rich hemipelagic sediments. Geochimica et Cosmochimica Acta, 71, 5698-5716.

Brese, N.E. and O'Keeffe, M. (1991) Bond-valence parameters for solids. Acta Crystallographica, B47, 192-197.

Brindley, G.W. (1980) Order-disorder in clay mineral structures. In G.W. Brindley and G. Brown, Eds., Crystal Structures of Clay Minerals and their X-ray Identification, p. 125-195. Mineralogical Society, London.

Brown, I.D. (1996) Valence: A program for calculating bond valences. Journal of Applied Crystallography, 29, 479-480.

Cheney, M.A., Sposito, G., McGrath, A.E., and Criddle, R.S. (1996) Abiotic degradation of 2,4-D (dichlorophenoxyacetic acid) on synthetic birnessite: A calorespirometric method. Colloids and Surfaces A: Physicochemical and Engineering Aspects, 107, 131-140.

Chorover, J. and Amistadi, M.K. (2001) Reaction of forest floor organic matter at goethite, birnessite and smectite surfaces. Geochimica et Cosmochimica Acta, 65, 95-109.

Crerar, D.A. and Barnes, H.L. (1974) Deposition of deep-sea manganese nodules. Geochimica et Cosmochimica Acta, 38, 279-300.

Crozier, E.D. (1997) A review of the current status of XAFS spectroscopy. Nuclear Instruments and Methods in Physics Research Section B Beam Interactions with Materials and Atoms, 133, 134-144.

De Schamphelaire, L., Rabaey, K., Boon, N., Verstraete, W., and Boeckx, P. (2007) Minireview: The potential of enhanced manganese redox cycling for sediment oxidation. Geomicrobiology Journal, 24, 547-558.

Drits, V.A., Silvester, E.J., Gorshkov, A.I., and Manceau, A. (1997) The structure of monoclinic Na-rich birnessite and hexagonal birnessite. Part 1. Results from $\mathrm{X}$-ray diffraction and selected area electron diffraction. American Mineralogist, 82, 946-961.

Drits, V.A., Lanson, B., Gorshkov, A.I., and Manceau, A. (1998) Substructure and superstructure of four-layer Ca-exchanged birnessite. American Mineralogist, 83, 97-118.

Drits, V.A., Lanson, B., Bougerol Chaillout, C., Gorshkov, A.I., and Manceau, A. (2002) Structure of heavy-metal sorbed birnessite: Part 2. Results from electron diffraction. American Mineralogist, 87, 1646-1661.

Drits, V.A., Lanson, B., and Gaillot, A.C. (2007) Birnessite polytype systematics and identification by powder X-ray diffraction. American Mineralogist, 92, $771-788$.

Gaillot, A.C. (2002) Caractérisation structurale de la birnessite: Influence du protocole de synthèse, 392 p. Ph.D. thesis, Université Joseph-Fourier, Grenoble I, France.

Gaillot, A.C., Flot, D., Drits, V.A., Manceau, A., Burghammer, M., and Lanson, B. (2003) Structure of synthetic K-rich birnessite obtained by high-temperature decomposition of $\mathrm{KMnO}_{4}$. I. Two-layer polytype from $800{ }^{\circ} \mathrm{C}$ experiment. Chemistry of Materials, 15, 4666-4678.

Gaillot, A.C., Drits, V.A., Plancon, A., and Lanson, B. (2004) Structure of synthetic K-rich birnessites obtained by high-temperature decomposition of $\mathrm{KMnO}_{4}$. 2. Phase and structural heterogeneities. Chemistry of Materials, 16, 1890-1905.

Gaillot, A.C., Lanson, B., and Drits, V.A. (2005) Structure of birnessite obtained from decomposition of permanganate under soft hydrothermal conditions. 1. Chemical and structural evolution as a function of temperature. Chemistry of Materials, 17, 2959-2975.

Gaillot, A.C., Drits, V.A., Manceau, A., and Lanson, B. (2007) Structure of the synthetic K-rich phyllomanganate birnessite obtained by high-temperature decomposition of $\mathrm{KMnO}_{4}$ - Substructures of K-rich birnessite from $1000{ }^{\circ} \mathrm{C}$ experiment. Microporous and Mesoporous Materials, 98, 267-282.

Giovanoli, R. (1980) Vernadite is random-stacked birnessite. Mineralium Deposita, $15,251-253$.

Grangeon, S., Lanson, B., Lanson, M., and Manceau, A. (2008) Crystal structure of Ni-sorbed synthetic vernadite: A powder X-ray diffraction study. Mineralogical Magazine, 72, 1279-1291.

Hochella, M.F., Kasama, T., Putnis, A., Putnis, C.V., and Moore, J.N. (2005a) Environmentally important, poorly crystalline Fe/Mn hydrous oxides: Ferrihydrite and a possibly new vernadite-like mineral from the Clark Fork River Superfund Complex. American Mineralogist, 90, 718-724.

Hochella, M.F., Moore, J.N., Putnis, C.V., Putnis, A., Kasama, T., and Eberl, D.D. (2005b) Direct observation of heavy metal-mineral association from the Clark Fork River Superfund Complex: Implications for metal transport and bioavail- 
ability. Geochimica et Cosmochimica Acta, 69, 1651-1663.

Howard, S.A. and Preston, K.D. (1989) Profile fitting of powder diffraction patterns. In D.L. Bish and J.E. Post, Eds., Modern Powder Diffraction, 20, p. 217-275. Reviews in Mineralogy, Mineralogical Society of America, Chantilly, Virginia.

Isaure, M.P., Manceau, A., Geoffroy, N., Laboudigue, A., Tamura, N., and Marcus, M.A. (2005) Zinc mobility and speciation in soil covered by contaminated dredged sediment using micrometer-scale and bulk-averaging X-ray fluorescence, absorption and diffraction techniques. Geochimica et Cosmochimica Acta, 69, 1173-1198.

Jürgensen, A., Widmeyer, J.R., Gordon, R.A., Bendell Young, L.I., Moore, M.M., and Crozier, E.D. (2004) The structure of the manganese oxide on the sheath of the bacterium Leptothrix discophora: An XAFS study. American Mineralogist, 89, 1110-1118.

Lanson, B., Drits, V.A., Silvester, E.J., and Manceau, A. (2000) Structure of Hexchanged hexagonal birnessite and its mechanism of formation from Na-rich monoclinic buserite at low $\mathrm{pH}$. American Mineralogist, 85, 826-838.

Lanson, B., Drits, V.A., Feng, Q., and Manceau, A. (2002a) Structure of synthetic Na-birnessite: Evidence for a triclinic one-layer unit cell. American Mineralogist, 87, 1662-1671.

Lanson, B., Drits, V.A., Gaillot, A.-C., Silvester, E., Plancon, A., and Manceau, A. (2002b) Structure of heavy-metal sorbed birnessite: Part 1. Results from X-ray diffraction. American Mineralogist, 87, 1631-1645.

Lanson, B., Marcus, M.A., Fakra, S., Panfili, F., Geoffroy, N., and Manceau, A. (2008) Formation of $\mathrm{Zn}-\mathrm{Ca}$ phyllomanganate nanoparticles in grass roots. Geochimica et Cosmochimica Acta, 72, 2478-2490.

Lingane, J.J. and Karplus, R. (1946) New method for determination of manganese. Industrial and Engineering Chemistry. Analytical Edition, 18, 191-194.

Manceau, A. and Combes, J.M. (1988) Structure of Mn and Fe oxides and hydroxides: A topological approach by EXAFS. Physics and Chemistry of Minerals, 15, 283-295.

Manceau, A., Drits, V.A., Silvester, E.J., Bartoli, C., and Lanson, B. (1997) Structural mechanism of $\mathrm{Co}^{2+}$ oxidation by the phyllomanganate buserite. American Mineralogist, 82, 1150-1175.

Manceau, A., Lanson, B., and Drits, V.A. (2002) Structure of heavy metal sorbed birnessite. Part III: Results from powder and polarized extended X-ray absorption fine structure spectroscopy. Geochimica et Cosmochimica Acta, 66, 2639-2663.

Manceau, A., Tamura, N., Celestre, R.S., MacDowell, A.A., Geoffroy, N., Sposito, G., and Padmore, H.A. (2003) Molecular-scale speciation of Zn and Ni in soil ferromanganese nodules from loess soils of the Mississippi Basin. Environmental Science and Technology, 37, 75-80.

Manceau, A., Marcus, M.A., Tamura, N., Proux, O., Geoffroy, N., and Lanson, B. (2004) Natural speciation of $\mathrm{Zn}$ at the micrometer scale in a clayey soil using $\mathrm{X}$-ray fluorescence, absorption, and diffraction. Geochimica et Cosmochimica Acta, 68, 2467-2483.

Manceau, A., Tommaseo, C., Rihs, S., Geoffroy, N., Chateigner, D., Schlegel, M., Tisserand, D., Marcus, M.A., Tamura, N., and Chen, Z.S. (2005) Natural speciation of $\mathrm{Mn}, \mathrm{Ni}$, and $\mathrm{Zn}$ at the micrometer scale in a clayey paddy soil using X-ray fluorescence, absorption, and diffraction. Geochimica et Cosmochimica Acta, 69, 4007-4034.

Manceau, A., Kersten, M., Marcus, M.A., Geoffroy, N., and Granina, L. (2007a) $\mathrm{Ba}$ and $\mathrm{Ni}$ speciation in a nodule of binary $\mathrm{Mn}$ oxide phase composition from Lake Baikal. Geochimica et Cosmochimica Acta, 71, 1967-1981.

Manceau, A., Lanson, M., and Geoffroy, N. (2007b) Natural speciation of Ni, Zn, $\mathrm{Ba}$, and $\mathrm{As}$ in ferromanganese coatings on quartz using X-ray fluorescence, absorption, and diffraction. Geochimica et Cosmochimica Acta, 71, 95-128.

Mandernack, K.W., Post, J., and Tebo, B.M. (1995) Manganese mineral formation by bacterial spores of the marine Bacillus, strain SG-1: Evidence for the direct oxidation of $\mathrm{Mn}(\mathrm{II})$ to $\mathrm{Mn}(\mathrm{IV})$. Geochimica et Cosmochimica Acta, 59, 4393-4408.

Marcus, M.A., MacDowell, A.A., Celestre, R., Manceau, A., Miller, T., Padmore, H.A., and Sublett, R.E. (2004b) Beamline 10.3.2 at ALS: a hard X-ray microprobe for environmental and materials sciences. Journal of Synchrotron Radiation, 11, 239-247.

Marcus, M.A., Manceau, A., and Kersten, M. (2004a) Mn, Fe, Zn and As speciation in a fast-growing ferromanganese marine nodule. Geochimica et Cosmochimica Acta, 68, 3125-3136.

McKenzie, R.M. (1980) The adsorption of lead and other heavy metals on oxides of manganese and iron. Australian Journal of Soil Research, 18, 61-73.

(1989) Manganese oxides and hydroxides. In J.B. Dixon and S.B. Weed, Eds., Minerals in Soil Environments, p. 439-465. Soil Science Society of America, Madison, Wisconsin, U.S.A.

Miyata, N., Tani, Y., Iwahori, K., and Soma, M. (2004) Enzymatic formation of manganese oxides by an Acremonium-like hyphomycete fungus, strain KR21-2 . Fems Microbiology Ecology, 47, 101-109.

Miyata, N., Maruo, K., Tani, Y., Tsuno, H., Seyama, H., Soma, M., and Iwahori, K. (2006a) Production of biogenic manganese oxides by anamorphic ascomycete fungi isolated from streambed pebbles. Geomicrobiology Journal,
$23,63-73$.

Miyata, N., Tani, Y., Maruo, K., Tsuno, H., Sakata, M., and Iwahori, K. (2006b) Manganese(IV) oxide production by Acremonium sp. strain KR21-2 and extracellular Mn(II) oxidase activity. Applied and Environmental Microbiology, 72, 6467-6473.

Miyata, N., Sugiyama, D., Tani, Y., Tsuno, H., Seyama, H., Sakata, M., and Iwahori, K. (2007a) Production of biogenic manganese oxides by repeated-batch cultures of laboratory microcosms. Journal of Bioscience and Bioengineering, $103,432-439$.

Miyata, N., Tani, Y., Sakata, M., and Iwahori, K. (2007b) Microbial manganese oxide formation and interaction with toxic metal ions. Journal of Bioscience and Bioengineering, 104, 1-8.

Morgan, J.J. (2005) Kinetics of reaction between $\mathrm{O} 2$ and Mn(II) species in aqueous solutions. Geochimica et Cosmochimica Acta, 69, 35-48.

Nasser, A., Sposito, G., and Cheney, M.A. (2000) Mechanochemical degradation of 2,4-D adsorbed on synthetic birnessite. Colloids and Surfaces a Physicochemical and Engineering Aspects, 163, 117-123.

Peacock, C.L. (2009) Physiochemical controls on the crystal-chemistry of Ni in birnessite: Genetic implications for ferromanganese precipitates. Geochimica et Cosmochimica Acta, 73, 3568-3578.

Peacock, C.L. and Sherman, D.M. (2007) Crystal-chemistry of Ni in marine ferromanganese crusts and nodules. American Mineralogist, 92, 1087-1092.

Pizzigallo, M.D.R., Napola, A., Spagnuolo, M., and Ruggiero, P. (2004) Mechanochemical removal of organo-chlorinated compounds by inorganic components of soil. Chemosphere, 55, 1485-1492.

Ressler, T. (1998) WinXAS: A program for X-ray absorption spectroscopy data analysis under MS-Windows. Journal of Synchrotron Radiation, 5, 118-122.

Saratovsky, I., Wightman, P.G., Pasten, P.A., Gaillard, J.F., and Poeppelmeier, K.R. (2006) Manganese oxides: Parallels between abiotic and biotic structures. Journal of the American Chemical Society, 128, 11188-11198.

Saratovsky, I., Gurr, S.J., and Hayward, M.A. (2009) The structure of manganese oxide formed by the fungus Acremonium $s p$. strain KR21-2. Geochimica et Cosmochimica Acta, 73, 3291-3300.

Silvester, E.J., Manceau, A., and Drits, V.A. (1997) The structure of monoclinic Narich birnessite and hexagonal birnessite. Part 2. Results from chemical studies and EXAFS spectroscopy. American Mineralogist, 82, 962-978.

Spiro, T.G., Bargar, J.R., Sposito, G., and Tebo, B.M. (2010) Bacteriogenic manganese oxides. Accounts of Chemical Research, 43, 2-9.

Stone, A.T. (1987) Reductive dissolution of manganese (III/IV) oxides by substituted phenols. Environmental Science and Technology, 21, 979-993.

Stone, A.T. and Ulrich, H.J. (1989) Kinetics and reaction stoichiometry in the reductive dissolution of manganese(IV) dioxide and cobalt(III) oxide by hydroquinone. Journal of Colloid and Interface Science, 132, 509-522.

Sunda, W.G. and Huntsman, S.A. (1988) Effect of sunlight on redox cycles of manganese in the Southwestern Sargasso Sea. Deep-Sea Research Part aOceanographic Research Papers, 35, 1297-1317.

Sunda, W.G. and Kieber, D.J. (1994) Oxidation of humic substances by manganese oxides yields low-molecular-weight organic substrates. Nature, 367, 62-64.

Takahashi, Y., Manceau, A., Geoffroy, N., Marcus, M.A., and Usui, A. (2007) Chemical and structural control of the partitioning of $\mathrm{Co}, \mathrm{Ce}$, and $\mathrm{Pb}$ in marine ferromanganese oxides. Geochimica et Cosmochimica Acta, 71, 984-1008.

Tani, Y., Miyata, N., Iwahori, K., Soma, M., Tokuda, S., Seyama, H., and Theng, B.K.G. (2003) Biogeochemistry of manganese oxide coatings on pebble surfaces in the Kikukawa River System, Shizuoka, Japan. Applied Geochemistry, $18,1541-1554$.

Tani, Y., Miyata, N., Ohashi, M., Ohnuki, T., Seyama, H., Iwahori, K., and Soma, M. (2004a) Interaction of inorganic arsenic with biogenic manganese oxide produced by a Mn-oxidizing fungus, strain KR21-2. Environmental Science and Technology, 38, 6618-6624.

Tani, Y., Ohashi, M., Miyata, N., Seyama, H., Iwahori, K., and Soma, M. (2004b) Sorption of $\mathrm{Co}(\mathrm{II}), \mathrm{Ni}(\mathrm{II})$, and $\mathrm{Zn}(\mathrm{II})$ on biogenic manganese oxides produced by a Mn-oxidizing fungus, strain KR21-2. Journal of Environmental Science and Health. Part A: Toxic/Hazardous Substances and Environmental Engineering, 39, 2641-2660

Tebo, B.M. (1991) Manganese(II) oxidation in the suboxic zone of the Black-Sea. Deep-Sea Research Part a-Oceanographic Research Papers, 38, S883-S905.

Tebo, B.M. and Emerson, S. (1985) Effect of oxygen-tension, Mn(II) concentration, and temperature on the microbially catalyzed $\mathrm{Mn}$ (II) oxidation rate in a marine fjord. Applied and Environmental Microbiology, 50, 1268-1273.

Tebo, B.M., Bargar, J.R., Clement, B.G., Dick, G.J., Murray, K.J., Parker, D., Verity, R., and Webb, S.M. (2004) Biogenic manganese oxides: Properties and mechanisms of formation. Annual Review of Earth and Planetary Sciences, 32, 287-328.

Teo, B.K. (1986) EXAFS: Basic Principles and Data Analysis, 349 p. SpringerVerlag, Berlin.

Toner, B., Manceau, A., Webb, S.M., and Sposito, G. (2006) Zinc sorption to biogenic hexagonal-birnessite particles within a hydrated bacterial biofilm. Geochimica et Cosmochimica Acta, 70, 27-43.

Tonkin, J.W., Balistrieri, L.S., and Murray, J.W. (2004) Modeling sorption of 
divalent metal cations on hydrous manganese oxide using the diffuse double layer model. Applied Geochemistry, 19, 29-53.

Vetter, K.J. and Jaeger, N. (1966) Potentialausbildung an der Mangan-dioxidelektrode als Oxidelektrode mit nichtstöchiometrischem Oxid. Electrochimica Acta, 11, 401-419.

Villalobos, M., Bargar, J.R., and Sposito, G. (2005) Mechanisms of Pb(II) sorption on a biogenic manganese oxide. Environmental Science and Technology, $39,569-576$.

Villalobos, M., Lanson, B., Manceau, A., Toner, B., and Sposito, G. (2006) Structural model for the biogenic Mn oxide produced by Pseudomonas putida. American Mineralogist, 91, 489-502.

Villatoro-Monzón, W.R., Mesta-Howard, A.M., and Razo-Flores, E. (2003) Anaerobic biodegradation of BTEX using $\mathrm{Mn}$ (IV) and Fe(III) as alternative electron acceptors. Water Science and Technology, 48, 125-131.

Warren, B.E. (1941) X-ray diffraction in random layer lattices. Physical Review, 59, 693-698.
Webb, S.M., Tebo, B.M., and Bargar, J.R. (2005) Structural characterization of biogenic Mn oxides produced in seawater by the marine Bacillus sp. strain SG-1. American Mineralogist, 90, 1342-1357.

Webb, S.M., Fuller, C.C., Tebo, B.M., and Bargar, J.R. (2006) Determination of uranyl incorporation into biogenic manganese oxides using $\mathrm{X}$-ray absorption spectroscopy and scattering. Environmental Science and Technology, 40, $771-777$.

Webster, R. (2001) Statistics to support soil research and their presentation. European Journal of Soil Science, 52, 331-340.

MANUSCRIPT RECEIVED FEBRUARY 1, 2010

MANUSCRIPT ACCEPTED JUNE 29, 2010

MANUSCRIPT HANDLED BY PUPA GILBERT 


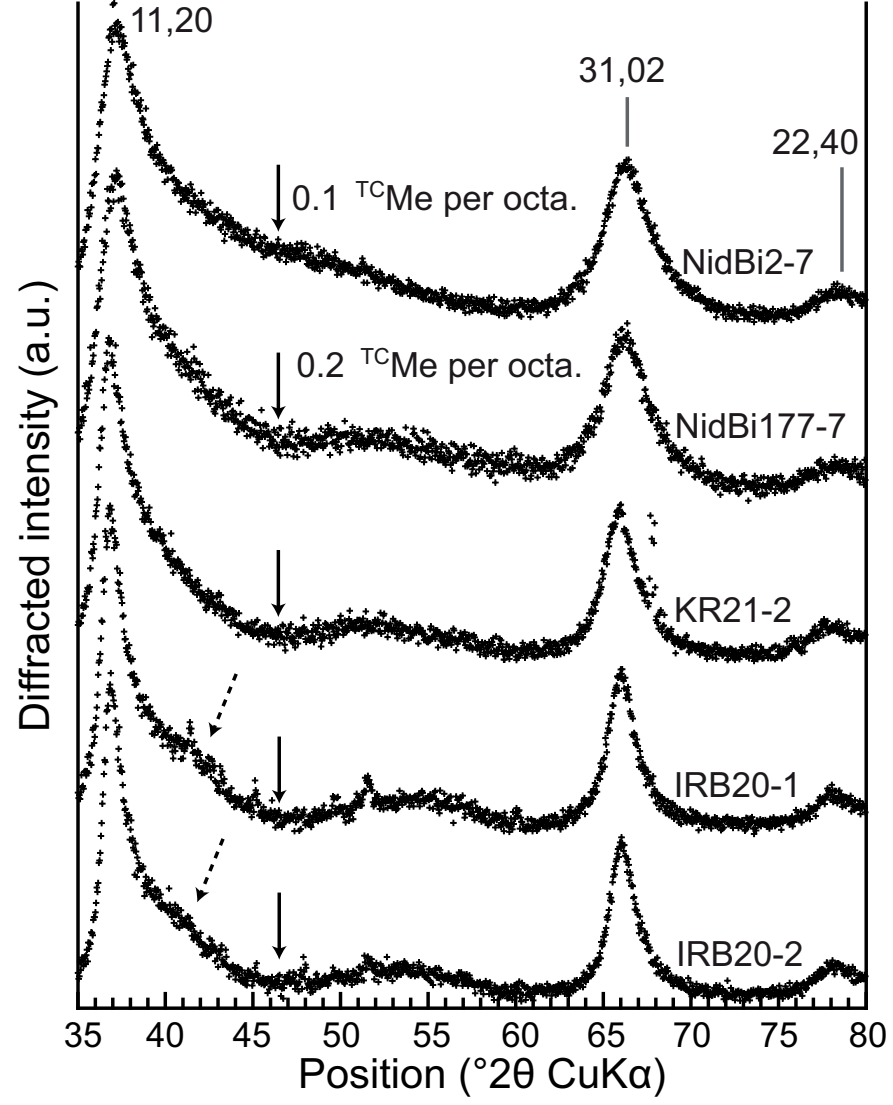

Figure SI1. X-ray diffraction patterns of fungal $\mathrm{Mn}$ oxides compared with Ni-sorbed $\delta-\mathrm{MnO}_{2}$ (Grangeon et al. 2008). NidBi2-7 and NidBi177-7 contain respectively 0.1 and 0.2 "heavy" interlayer cations ( $\mathrm{Ni}$ and $\mathrm{Mn}$ ) at TC position. Solid arrows point out the intensity minimum appearing at $\sim 47^{\circ} 2 \theta$ when the amount of interlayer Me cations at TC position increases from 0.1 to 0.2 per layer octahedron. When this number exceeds 0.2 , a shoulder appears at $\sim 42^{\circ} 2 \theta$ (dashed arrow). 


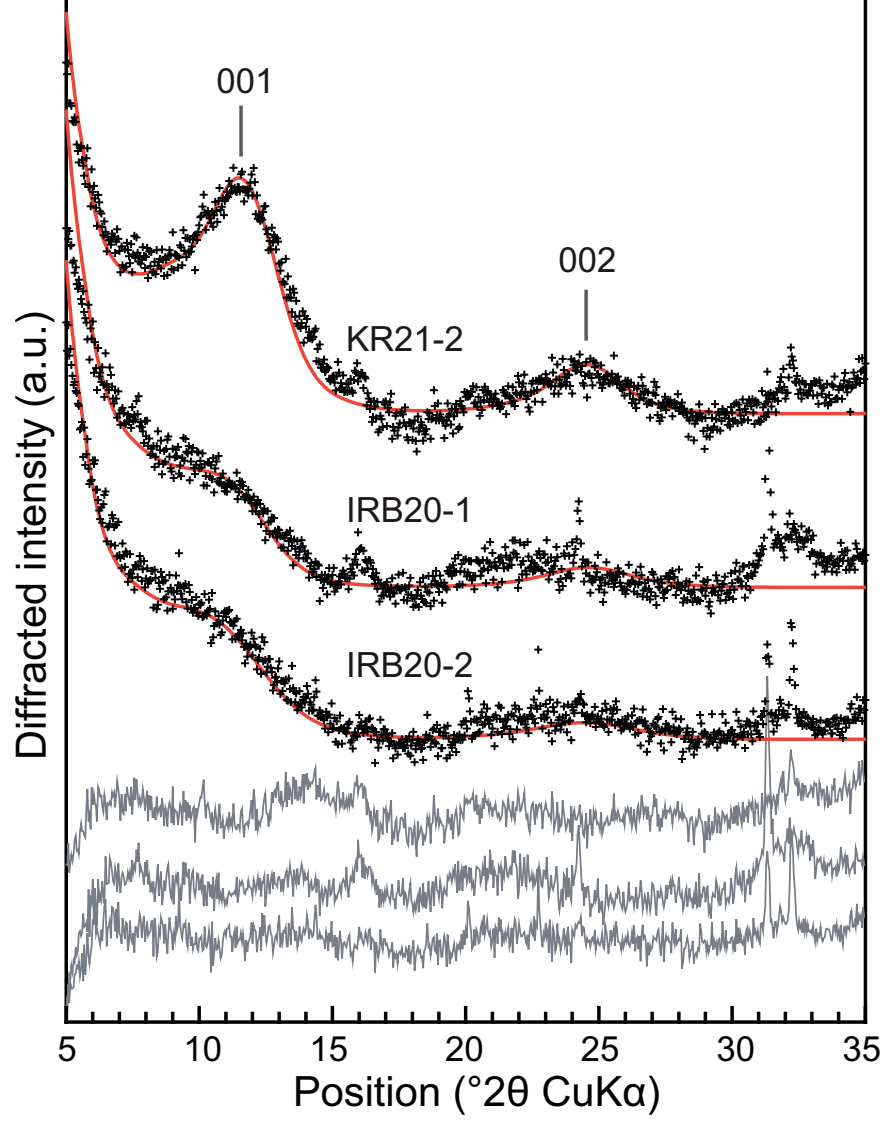

Figure SI2. Experimental (black crosses) and calculated (red lines) intensities of the 001 and 002 reflections. Difference plots are shown at the bottom of the figure. Structure models are described in Tables 1 and 2. The cell contribution (Fig. 1) was subtracted from the experimental data. 

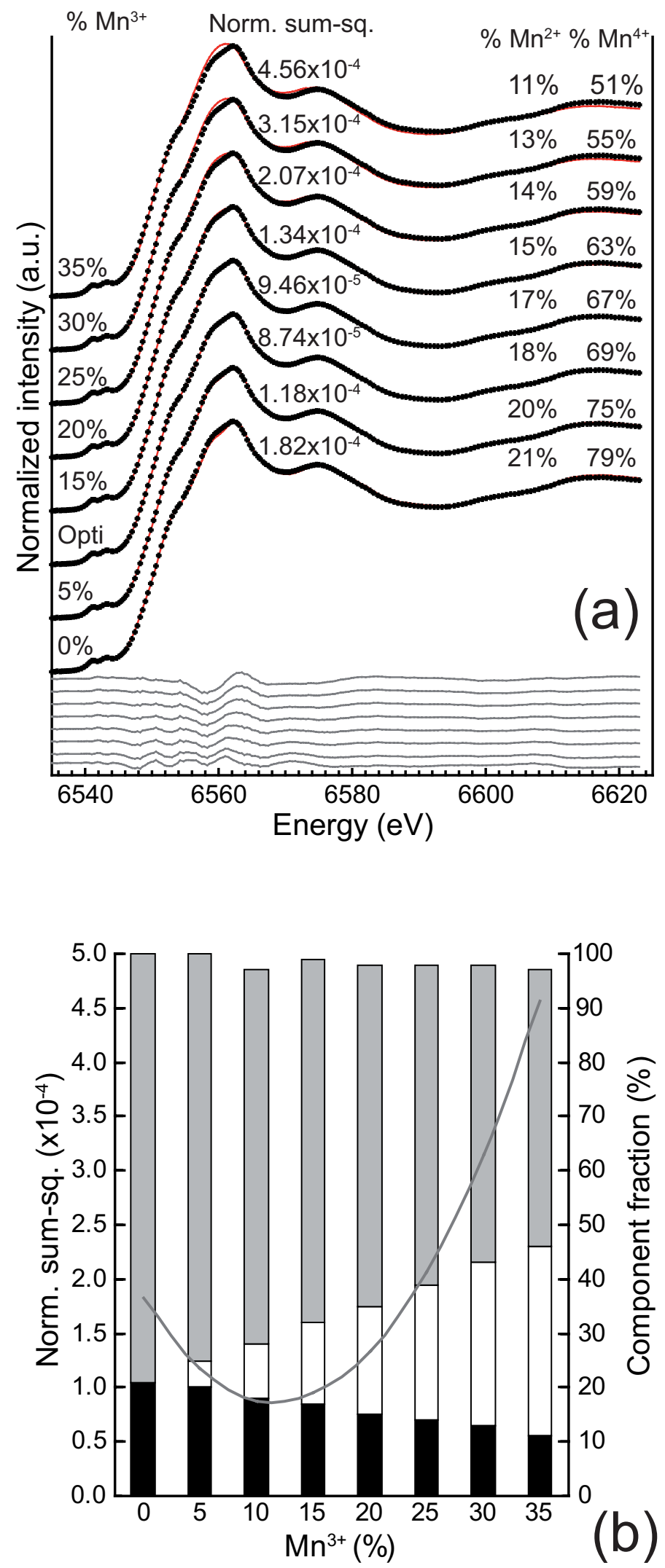

Figure SI3. Sensitivity of XANES spectra to the relative abundance of $\mathrm{Mn}^{3+}$, taking IRB20-1 (crosses) as an example. The fits shown in red on (a) were obtained by fixing the $\mathrm{Mn}^{3+}$ content (feitknechtite) successively from $0 \%$ to $35 \%$ ( $5 \%$ steps), and optimizing in each case the proportions of $\mathrm{Mn}^{4+}$ (chalcophanite) and $\mathrm{Mn}^{2+}$ (sorbec on fungal cells). b) Evolution of the fit quality (solid line) and of the proportions of $\mathrm{Mn}^{4+}$ (light grey bars) and $\mathrm{Mn}^{2+}$ (black bars) as a function of the fixed $\mathrm{Mn}^{3+}$ content (open bars). X-ray diffraction patterns of fungal $\mathrm{Mn}$ oxides compared with Ni-sorbed $\delta-\mathrm{MnO}_{2}$ (Grangeon et al. 2008). NibBi2-7 and NidBi177-7 contain respectively 0.1 and 0.2 "heavy" interlayer cations ( $\mathrm{Ni}$ and $\mathrm{Mn}$ ) at TC position. Solid arrows point out the intensity minimum appearing at $\sim 47^{\circ} 2 \theta$ when the amount of interlayer Me cations at TC position increases from 0.1 to 0.2 per layer octahedron. When this number exceeds 0.2 , a shoulder appears at $\sim 42^{\circ} 2 \theta$ (dashed arrow). 


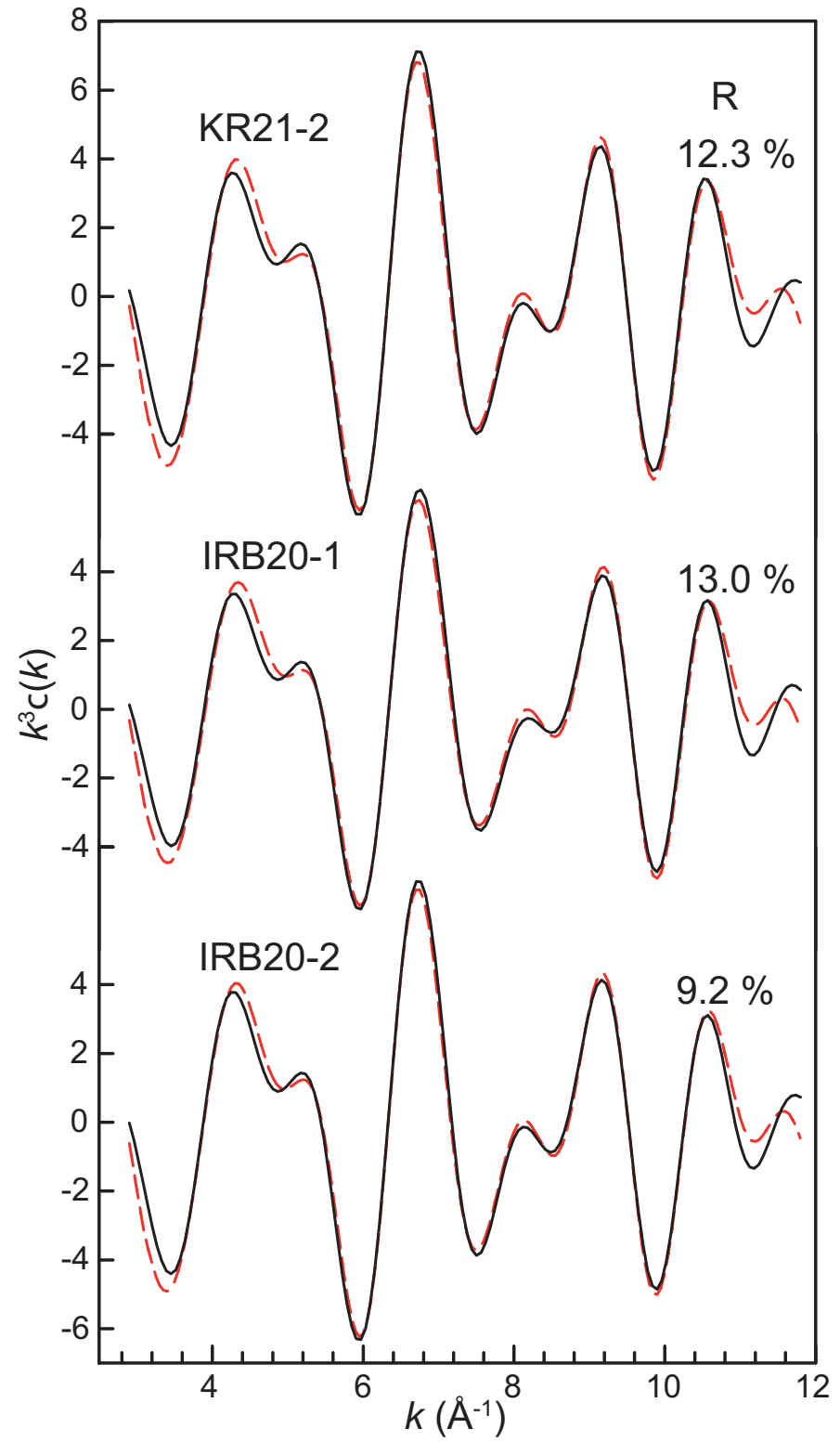

Figure S14. Partial EXAFS spectra Fourier-filtered over the 0.8-3.3 $\AA R+\Delta R$ interval (black) with the optimum single-scattering simulations (red). $R$ is the sum of the residuals, normalized to the sum of the data values. 